\title{
Pengaruh customer relationship management (CRM) terhadap citra perpustakaan pada UPT Perpustakaan ITB
}

\author{
Kamaludin ${ }^{1}$, Yooke Tjuparmah ${ }^{2}$, dan Hana Silvana ${ }^{3}$ \\ 1,2,3 Universitas Pendidikan Indonesia
}

\begin{abstract}
ABSTRAK
Customer Relationship Management (CRM) merupakan strategi yang digunakan oleh UPT Perpustakaan Institut Teknologi Bandung (ITB) untuk menjalin hubungan yang baik pada pemustaka. Selain keberadaan UPT Perpustakaan ITB sebagai perpustakann pusat, juga terdapat perpustakaan khusus di setiap fakultas maupun program studi yang menjadi pilihan mahasiswa dalam mengakses sumber informasi. Strategi dalam menjalin hubungan baik dengan pemustaka agar menjaga popularitas dalam menjaga citra baik UPT Perpustakaan ITB menjadi daya tarik untuk diteliti. Tujuan penelitian ini adalah untuk mengetahui 1) Pengaruh CRM terhadap citra UPT Perpustakaan ITB; 2) seberapa besar pengaruh data dan teknologi CRM terhadap citra UPT Perpustakaan ITB; 3) seberapa besar pengaruh sumber daya manusia customer relationship management terhadap citra UPT Perpustakaan ITB; 4) Seberaha besar pengaruh proses CRM terhadap citra UPT Perpustakaan ITB. Penelitian ini menggunakan metode deksriptif dengan pendekatan kuantitatif. Sampel dari penelitian ini adalah mahasiswa ITB dengan kategori minimal sebagai mahasiswa semester 2 dan memanfaatkan layanan perpustakaan. Teknik penentuan sampel pada penelitian ini adalah teknik purposive sampling. Instrumen yang digunakan pada penelitian ini menggunakan angket dengan skala Likert yang dianalisis menggunakan analisis regresi linier sederhana. Hasil penelitian ini menyimpulkan bahwa terdapat pengaruh yang positif dan signifikan dari customer relationship management terhadap citra UPT Perpustakaan Institut Teknologi Bandung baik dari aspek data dan teknologi, sumber daya manusia, maupun proses customer relationship management.
\end{abstract}

Kata-kata Kunci: Citra; CRM; layanan; pemustaka; perpustakaan

\section{The effect of customer relationship management on library image at the ITB library}

\begin{abstract}
Customer relationship management (CRM) is a strategy used by the UPT Bandung Institute of Technology (ITB) library to establish good relationships with users. The strategy in establishing good relations with users in order to maintain popularity in maintaining a good image of the UPT ITB Library is an attraction to be studied. The purpose of this research was to find out 1) the effect of CRM towards the image of the UPT ITB Library; 2) The greater of the influence of data and CRM technology on the image of the UPT ITB Library; 3) The greater of influence of CRM human resources on the image of the UPT ITB Library; 4) The greater of the influence of the CRM process on the image of the UPT ITB Library. This study uses a descriptive method with a quantitative approach. The sample of this study is students of ITB with a minimum category of the second semester and utilize library services. The sample determination technique in this study was purposive sampling technique. The instrument used in this study is a questionnaire using a Likert scale which was analyzed using simple linear regression analysis. The results of this study conclude that there is a positive and significant influence of CRM on the image of the UPT ITB Library both in terms of data and technology, human resources, and customer relationship management process.
\end{abstract}

Keywords: CRM; image; library; service; user

Korespondensi: Kamaludin, S.S.I Universitas Pendidikan Indonesia. Jl. Dr. Setiabudhi No 229 Bandung 40154.Email: Kamaludin45@student.upi.edu 


\section{PENDAHULUAN}

Beragam cara telah dilakukan oleh perpustakaan untuk terus meningkatkan pelayanan yang berkualitas agar memperoleh kepuasan pemustaka dan tentunya akan memberikan kesan yang baik dari pemustaka terhadap citra perpustakaan. Dengan demikian, maka perpustakaan perlu meningkatkan layanan kebutuhan informasi serta menjalin hubungan yang baik kepada pemustaka agar dapat memperoleh kepuasan dan kesan yang baik pada perpustakaan.

Customer relationship management (CRM) atau manajemen hubungan pelanggan hadir untuk membantu meningkatkan kepuasan dan mempertahankan hubungan yang baik dengan pelanggan agar tercipta rasa loyalitas tinggi kepada perusahaan. Peningkatan relasi antara pelanggan dengan perusahaan, dapat dilakukan dengan memperhatikan tiga aspek, yaitu teknologi, seperti penerapan customer relationship management, serta global competition seperti persaingan yang terjadi antara produk yang satu dengan produk lainnya (Darudiato, Novianto, Hendra, Reynaldo, \& Selvi, 2011). Bentuk penerapan CRM di perpustakaan dapat dilakukan melalui bentuk pelayanan prima yang difokuskan dalam menjalin hubungan yang harmonis dengan pemustaka agar memperoleh kepuasan baik dari aspek kebutuhan koleksi, pelayanan teknis hingga kepuasan emosional.

Penelitian ini bertujuan untuk mengetahui seberapa besar pengaruh customer relationship management (CRM) terhadap suatu citra perpustakaan, beberapa indikator atau sub variabel yang terdapat dalam CRM yaitu data dan teknologi, sumber daya manusia (pustakawan), dan proses CRM yang diaplikasikan perpustakaan.

Beberapa hasil penelitian telah mengungkapkan bahwa customer relationship management (CRM) dapat memengaruhi citra suatu lembaga atau perusahaan. Penelitian yang berjudul "Pengaruh Customer Relationship Management (CRM) dan Good Corporate Governance (GCG) Terhadap Citra (Image) Perusahaan (Studi pada Perusahaan Daerah Air Minum Tirta Mangutama Kabupaten Bandung) menunjukan bahwa CRM berpengaruh positif dan signifikan terhadap citra perusahaan Daerah AirMinum Tirta Mangutama. Fokuspeningkatan untuk CRM adalah pada peningkatan SDM, teknologi dan proses peningkatan pelayanan (Wijaya \& Sukawati, 2016).

Penerapan CRM pada perusahaan rata-rata digunakan untuk menjalin hubungan yang baik antara perusahaan dengan pelanggannya agar menciptakan kepuasan dan loyalitas pelanggan melalui bentuk pelayanan yang berkualitas. Di perpustakaan, penerapan CRM masih dirasa 
kurang populer karena memang secara tidak langsung perpustakaan mencoba meningkatkan kualitas pelayanan melalui berbagai aspek terutama teknologi informasi dan komunikasi.

UPT Perpustakaan ITB telah menerapkan beberapa teknologi penunjang pelayanan perpustakaan yang telah terintegrasi ke dalam sebuah software untuk meningkatkan kualitas layanan perpustakaan. Salah-satu bentuk penerapan teknologi di bidang perpustakaan yaitu website perpustakaan yang begitu lengkap. Selain menyajikan profil lengkap perpustakaan, website tersebut juga menyajikan berbagai bentuk layanan online yang terdiri dari katalog digital, perpustakaan digital, usulan koleksi, katalog induk, e-journal, e-book, dan e-kliping.

Di beberapa fakultas telah memiliki perpustakaan khusus fakultas dan didukung dengan perpustakaan-perpustakaan di setiap program studi. Adanya perpustakaan di setiap fakultas dan program studi menuntut UPT Perpustakaan ITB sebagai perpustakaan pusat agar lebih menjalin kerjasama dalam memenuhi kebutuhan informasi. Peneliti menganggap bahwa hal tersebut merupakan suatu masalah yang dapat berpengaruh terhadap citra perpustakaan. UPT Perpustakaan ITB dituntut untuk tetap menjaga nama baik atau citra perpustakaan melalui berbagai layanan yang maksimal kepada pemustaka agar lebih maksimal dalam memanfaatkan layanan perpustakaan pusat meskipun terdapat berbagai perpustakaan yang dapat dikatakan sebagai suatu saingan.

Berdasarkan hasil telaah peneliti terkait kondisi layanan UPT Perpustakaan Institut Teknologi Bandung yang terdapat di lapangan, peneliti tertarik dan bermaksud untuk mengkajinya lebih lanjut melalui sebuah penelitian yang berbeda dari penelitian sebelumnya. Penelitian ini lebih difokuskan pada citra perpustakaan sebagai variabel terikatnya.

Perpustakaan perguruan tinggi adalah perpustakaan yang berada di lingkungan perguruan tinggi dan bertujuan untuk memenuhi kebutuhan informasi setiap civitas akademika di lingkungannya. Dikatakan dalam Undang-undang nomor 43 tahun 2007 bahwa "setiap perguruan tinggi menyelenggarakan perpustakaan yang memenuhi standar nasional perpustakaan dengan memperhatikan Standar Nasional Pendidikan". Oleh karena itu, perpustakaan perguruan tinggi harus memperhatikan aspek-aspek penting dalam menunjang kebutuhan informasi civitas akademika agar dapat mewujudkan Tri Dharma Perguruan Tinggi yang meliputi pendidikan, penelitian, dan pengabdian pada masyarakat. Perpustakaan perguruan tinggi merupakan jantungnya perguruan tinggi, keberadaannya merupakan komponen vital yang tidak 
dapat dikesampingkan (Mubasyaroh, 2016). Sehingga maju mundurnya perguruan tinggi dapat dipengaruhi oleh kualitas perpustakaan yang dapat ditinjau dari beberapa aspek seperti jumlah referensi/buku yang tersedia, fasilitas yang memadai, serta pelayanan yang diberikan.

Dengan adanya perpustakaan perguruan tinggi maka diharapkan mampu meningkatkan atmosfer/iklim akademik yang baik sesuai dengan yang dicantumkan pada Standar Nasional Pendidikan.

Tujuan adanya Perpustakaan perguruan tinggi adalah untuk memfasilitasi keperluan sumber informasi bagi civitas akademika dan masyarakat umum. Sebagaimana yang tercantum pada Standar Nasional Perpustakaan tahun 2011 yang menyatakan bahwa untuk memenuhi kebutuhan informasi pengajar dan mahasiswa di perguruan tinggi dan dapat dibuka untuk publik. Sesuai dengan standar yang telah ditetapkan tersebut, maka perpustakaan perguruan tinggi selain sebagai sarana pembelajaran bagi mahasiswa dan pengajar juga menjadi akses publik bagi pemustaka diluar civitas akademika untuk mengakses sumber informasi di perpustakaan sesuai dengan kebijakan yang ada di setiap perpustakaan perguruan tinggi.

Adapun beberapa fungsi yang tercantum dalam Buku Pedoman Perpustakaan Perguruan Tinggi Depdiknas tahun2004 bahwa fungsi perpustakaan perguruan tinggi yaitu terdiri dari fungsi edukasi, informasi, riset, rekreasi, publikasi, deposit, dan interpretasi.

Pada perpustakaan perguruan tinggi, terdapat beberapa jenis layanan yang mesti dilaksanakan untuk memperoleh kepuasan pemustaka di perpustakaan. Berdasarkan Standar Nasional Perpustakaan tahun 2011, jenis layanan perpustakaan perguruan tinggi sekurang-kurangnya meliputi layanan sirkulasi, layanan referensi, layanan informasi, dan layanan teknologi informasi dan komunikasi.

Layanan sirkulasi di perpustakaan merupakan layanan yang disediakan untuk meminjam daan mengembalikan koleksi perpustakaan. Dalam dunia perpustakaan, arti sirkulasi adalah perputaran buku atau jenis koleksi lain milik perpustakaan yang dipinjam kepada anggota untuk beberapa waktu lamanya (Prastowo, 2012). Dengan demikian, maka layanan sirkulasi dapat memfasilitasi pemustaka yang tidak bisa membaca langsung di perpustakaan dengan cara meminjamnya dalam kurun waktu yang telah ditentukan.

Pemustaka yang merasa kesulitan dalam memperoleh sumber informasi yang kurang relevan dengan kebutuhannya maka dapat memanfaatkan layanan referensi yang terdapat di perpustakaan. Menurut American Library Association (ALA) layanan referensi adalah sebagian layanan perpustakaan yang secara 
langsung berhubungan dengan pembaca dalam memberikan informasi dan penggunaan sumbersumber perpustakaan untuk kepentingan studi dan penelitian (Saleh \& Komalasari, 2009). Dengan adanya layanan referensi, maka akan membantu pemustaka dalam memanfaatkan koleksi-koleksi perpustakaan dengan pilihan yang lebih luas, cepat dan tepat guna. Pemustaka dapat memberikan pertanyaan terkait sumber informasi yang dibutuhkan kepada pustakawan serta bimbingan untuk memakai dan menemukan koleksi referensi yang dibutuhkan.

Perpustakaan selalu meningkatkan layanan-layanan yang dapat memenuhi kebutuhan informasi khususnya dalam proses pembelajaran. Pada perguruan tinggi, perpustakaan dituntut untuk membantu terlaksananya Tri Dharma perguruan tinggi dengan memfasilitasi pemustaka dengan koleksi informasi yang dapat digunakan dalam kegiatan pembelajaran. Pemustaka dapat meningkatkan kemampuan belajar dan berkomunikasi secara mandiri melalui literasi informasi. Menurut Literasi infromasi adalah suatu kemampuan untuk belajar terus-menerus secara mandiri dan untuk berkomunikasi (Gunawan, 2008). Dengan demikian, perpustakaan dapat membantu pemustaka agar dapat belajar secara mandiri dan lebih meningkatkan kemampuannya dalam memanfaatkan sumber informasi.

Peran teknologi dan informasi tentunya menjadi sebuah solusi dalam meningkatkan layanan di perpustakaan. Layanan Teknologi Informasi dan Komunikasi (TIK) dapat membantu pemustaka dalam memanfaatkan koleksi maupun layanan di perpustakaan agar lebih efektif dan efisien. Sebagian besar civitas akademika kampus di era teknologi saat ini sudah tidak dapat dipungkiri bahwa cenderung lebih mengandalkan layanan internet dalam mencari sumber informasi yang berkaitan dengan kebutuhan akademik (Habir, 2015). Akibatnya, tingkat kunjungan secara langsung ke perpustakaan kampus pun mulai menurun . Tentunya hal ini menjadi perhatian khusus bagi pustakawan dalam meningkatkan kembali minat kunjung ke perpustakaan perguruan tinggi.

Berdasarkan Standar Nasional

Perpustakaan tahun 2011), perpustakaan perguruan tinggi dalam kegiatan layanan dan organisasi informasi memanfaatkan teknologi informasi dan komunikasi untuk meningkatkan kinerja perpustakaan dan keperluan pemustaka. Dengan demikian, layanan TIK dapat membantu perpustakaan dalam mengorganisasikan informasi melalui sistem informasi yang didukung oleh teknologi yang digunakan di perpustakaan. Selain digunakan dalam meningkatkan kinerja organisasi di perpustakaan, layanan TIK berperan penting dalam membantu pemustaka dalam memenuhi kebutuhan informasi khsususnya dalam 
mengakses serta memanfaatkan koleksi perpustakaan

\section{Customer Relationship Management} (CRM) atau manajemen hubungan pelanggan merupakan suatu kegiatan di dalam manajemen dalam menjalin hubungan yang baik antara organisasi atau perusahaan dengan pelanggannya. Zikmund dan Gilbert pada tahun 2003 menyatakan menyatakan bahwa CRM adalah suatu proses pengumpulan informasi yang akan meningkatkan pemahaman terhadap bagaimana mengelola hubungan organisasi dengan pelanggannya (Oesman, 2010).

Selain itu, CRM merupakan strategi bisnis inti yang memadukan proses dan fungsi internal, jaringan eksternal untuk menciptakan dan menyampaikan nilai kepada pelanggan untuk mendapatkan keuntungan (Buttle, 2004). CRM didasarkan pada data pelanggan berkualitas dan dimungkinkan dengan adanya teknologi informasi. Dengan demikian CRM dapat disimpulkan sebagai suatu strategi yang dapat digunakan untuk menjalin hubungan baik dengan pelanggan agar mendapat kepuasan terhadap suatu perusahaan atau lembaga tersebut.

Sebagai upaya merebut hati pelanggan, maka perusahaan perlu menerapkan strategi CRM dengan mengalokasikan seluruh sumber daya yang ada dalam perusahaan supaya tercapainya kepuasan pelanggan (Ningsih
\& Suharyono, 2016). Secara umum dapat dikatakan bahwa tujuan setiap strategi CRM adalah untuk mengembangkan hubungan yang menguntungkan dengan pelanggan (Buttle, 2004).

Penerapan CRM pada perusahaan rata-rata digunakan untuk menjalin hubungan yang baik antara perusahaan dengan pelanggannya agar menciptakan kepuasan dan loyalitas pelanggan melalui bentuk pelayanan yang berkualitas. Menurut Lovelock \& Wright bahwa loyalitas pelanggan merupakan suatu bentuk kesediaan agar terus berlangganan pada perusahaan dalam waktu jangka panjang, dengan cara membeli barang serta bersedia merekomendasikannya kepada orang-orang di sekitarnya (Ningsih \& Suharyono, 2016). Dengan demikian, pelanggan yang memiliki loyalitas tinggi maka perpusahaan wajib mempertahankannya dengan cara menjalin hubungan yang baim secara jangka panjang melalui manajamen hubungan pelanggan yang disebut dengan istilah CRM tersebut.

Di perpustakaan, penerapan CRM masih dirasa kurang populer karena memang secara tidak langsung perpustakaan mencoba meningkatkan kualitas pelayanan melalui berbagai aspek terutama teknologi informasi dan komunikasi. Penerapan strategi CRM yang sesuai dengan aspek-aspek pendukung akan lebih meningkatkan perhatian pemustaka pada 
perpustakaan.

Dengan demikian, perpustakaan dapat memanfaatkan strategi CRM agar dapat lebih menjalin hubungan yang baik dan menguntungkan baik pada pemustaka maupun perpustakaan.

CRM is an integrated business strategy that integrates internal factors and external factors by means of analysis of customer data using information technology, in order to gain the attention of customers to achieve lifetime value so that companies and customers gain advantages and benefits (Sutrisno, Brahmasari, \& Panjaitan, 2016).

Dalam keberhasilan sebuah kegiatan CRM, terdapat beberapa kondisi pendukung yang membantu kegiatan CRM agar terlaksana dengan baik dan hasil yang baik. Terdapat beberapa kondisi pendukung keberhasilan kegiatan CRM yaitu data dan teknologi, sumber daya manusia, dan proses (Buttle, 2004). Dengan adanya pendukung keberhasilan tersebut, maka kegiatan CRM yang diaplikasikan di perpustakaan akan dapat terlaksana dengan baik.

Data dan teknologi Di perpustakaan, data pemustaka dapat dijadikan sumber informasi bagi perpustakaan dalam menerapkan CRM di perpustakaan untuk menjalin hubungan yang baik dengan pemustaka. Perpustakaan memerlukan data yang andal agar membantu kegiatan CRM khususnya dalam promosi dan penyebarluasan informasi kebutuhan pemustaka dengan tepat, The user of CRM solution needs reliable customer data to perform marketing and sales actions appropriately (Brambilla \& Dalmarco, 2014).

Rigby menyebutkan bahwa CRM memungkinkan perusahaan untuk mengumpulkan data pelanggan dengan cepat, kemudian mengidentifikasi pelanggan yang paling berharga dari waktu ke waktu, serta berusaha meningkatkan loyalitas pelanggan melalui peyediaan produk dan layanan yang disesuaikan dengan kebutuhan pelanggan (Irina \& Diana, 2009). Oleh karena itu, perpustakaan perlu mengumpulkan dan menyimpan data pemustakanya agar menjadi sebuah informasi yang dapat digunakan untuk melayani kebutuhan pemustaka secara cepat dan tepat guna. Payne \& Frow pada tahun 2005 menyatakan bahwa proses CRM terdiri dari bagian-bagian yang berbeda, salah satunya yaitu terkait dengan proses pengumpulan informasi pelanggan, analisis dan penggunaan oleh karyawan perusahaan (Klimanov \& Frolkina, 2015). Perpustakaan mengumpulkan data pemustaka dapat melalui kartu anggota maupun identitas lainnya, dengan maksud untuk dipergunakan dalam menjalin hubungan atau relasi baik secara tatap muka mapun melalui jaringan komunikasi 
lainnya seperti email, telepon, serta jaringan lain agar relasi antar perpustakaan dengan pemustaka dapat terjaga dengan baik.

Pada tahap keintiman dengan pelanggan bertugas untuk memperoleh data tentang pelanggan yang akan membantu perusahaan untuk menjalin hubungan yang lebih erat dengan pelanggan (Buttle, 2004). Begitupun di perpustakaan, data pemustaka sangan penting untuk membantu perpustakaan agar menjalin hubungan yang erat dengan pemustaka. Terdapat beberapa data yang mesti diperoleh oleh perpustakaan dalam kegiatan CRM diantaranya seperti data kontak pelanggan, catatan peminjaman, alasan berkunjung ke perpustakaan, kepuasan pelanggan, saluran komunikasi yang dipilih, serta seberapa besar kemungkinan pemustaka akan merekomendasikan perpustakaan kepada orang lain. Dengan demikian, pemustaka bisa menanyakan ke perpustakaan tanpa harus datang secara langsung ke perpustakaan hanya dengan memanfaatkan layanan e-mail, telpon, sms, chatting, maupun jaringan komunikasi lainnya yang disediakan oleh perpustakaan. Maka dari itu, pustakawan diharapkan dapat berperan aktif dalam melayani kebutuhan pemustaka.

Teknologi di perpustakaan menjadi salahsatu komponen penting dalam mendukung kegiatan CRM. Teknologi informasi merupakan wahana pendukung berbagai kegiatan bisnis yang amat mempuni, wajar saja kalau teknologi itu menjadi bagian dari CRM (Buttle, 2004). Oleh karena itu, penggunaan teknologi untuk menjalin hubungan dengan pemustaka akan membantu perpustakaan dalam mendukung pengaplikasian CRM di perpustakaan.

PenggunaanteknologiCRMdiperpustakaan dalam menjalin hubungan dengan pemustaka akan saling menguntungkan. Hal tersebut memungkinkan informasi yang terintegrasi yang akan mempengaruhi pemustaka untuk memenuhi kebutuhan informasinya dengan lancar dan efisien. Hal tersebut seperti apa yang disampaikan oleh Mukerjee and Singh pada tahun 2009:

"the use of CRM technology is expected to enhance the company's capability to sustain profitable customer relationships by the enabling information integration and sharing that influences smooth and efficient firm-customer interactions, appropriate analysis of customer data and customization of response" (Mohammad \& Tahir, 2013)

Sangat penting dalam membantu perpustakaan dalam memenuhi kebutuhan pemustaka secara cepat dan akurat. Sehingga dengan terpenuhinya kebutuhan pemustaka maka pemustaka dapat merasa puas pada perpustakaan. Manajemen hubungan pelanggan telah berkembang dari teknologi terpisah yang mencakup pusat layanan telepon, sistem otomatisasi tenaga penjualan, dan file-file informasi pelanggan (Buttle, 2004). Perpustakaan dapat merekomendasikan 
koleksi perpustakaan terbaru, maupun koleksi yangdiinginkan pemustaka melalui saluran telepon, email, atau media lain. Oleh karena itu, CRM di perpustakaan akan berdampak baik pada kualitas pelayanan pemustaka.

Sumber daya manusia dibutuhkan dalam proses pengembangan strategi CRM yang diterapkan di sebuah perpustakaan. Sumber daya manusia merupakan kondisi pendukung bagi keberhasilan penerapan CRM (Buttle, 2004). Tidak hanya pada CRM saja, sumber daya manusia memang menjadi faktor penting bahkan di semua lini organisasi. Salah satu organisasi relokasi global terkemuka menemukan bahwa penerapan strategi CRM membutuhkan banyak partisipasi, pemahaman, dan penguatan di antara pegawai (Buttle, 2004). Dengan pernyataan tersebut maka sumber daya manusia memiliki peranan penting dalam berpartisipasi, pemahaman atau pembelajaran di setiap organisasi, serta keterampilanketerampilan tiap individu. Karena melalui SDM maka komunikasi antarpersonal akan lebih terjaga dalam setiap menjalin relasi dengan pemustaka. Aspek komunikasi yang ada pada customer service berperan pada penilaian publik terhadap perusahaan (Negoro, 2014). Dari pernyataan tersebut, ternyata peran sumber daya manusia memang sangatlah penting bagi kegiatan CRM meskipun ditunjang telah didukung dengan teknologi informasi.
Proses merupakan segala sesuatu yang dilakukan sesuai prosedur yang ada. Jika dilihat dari perspektif CRM, proses perlu dirancang dan dioperasikan sehingga mereka berkontribusi bagi penciptaan nilai atau setidaknya tidak merusak nilai yang telah diciptakan bagi pelanggan (Buttle, 2004). Lebih jelas lagi Buttle menjelaskan proses dalam CRM dapat dibagi menjadi beberapa kategori, diantaranya proses front office dan back office. Proses front officeadalah proses-proses yang berhadapan dengan pelanggan, sedangkan proses back office adalah proses yang tersembunyi dari pelanggan (Buttle, 2004). Dengan demikian, front office yaitu proses pelayanan yang berhadapan langsung dengan pelanggan, contohnya seperti proses menajemen keluhan pelanggan. Sedangkan back office yaitu proses yang tersembunyi dari pelanggan, contohnya seperti proses pengadaan.

Citra adalah cara bagaimana pihak lain memandang sebuahperusahaan, seseorang, suatu komite, atau suatu aktivitas. Katz pada di tahun 1994 sudah menyatakan bahwa berbagai citra perusahaan datang dari pelanggan perusahaan, pelanggan potensial, staf perusahaan, pesaing, distributor, pemasok, asosiasi dagang, dan gerakan pelanggan di sektor perdagangan yang mempunyai pandangan terhadap perusahaan. Franks J pada tahun 2010 di dalam bukunya yang berjudul Public Relations Technique, 
menyimpulkan bahwa secara umum, citra diartikan sebagai kesan seseorang atau individu tentang sesuatu yang muncul sebagai hasil dari pengetahuan dan pengalamannya (Soemirat \& Ardianto, 2010). Dengan demikian maka citra merupakan kesan yang muncul dari seseorang untuk menilai suatu hal tertentu yang memiliki nilai positif atau negatif.

Penilaian citra perpustakaan dapat ditunjukkan melalui pandangan atau kesan pemustaka terhadap perpustakaan tersebut. Layaknya sebuah perusahaan, perpustakaan juga memliki citra di mata pemustakanya. citra suatu perpustakaan dapat dikatakan sebagai suatu pandangan yang diberikan masyarakat tentang sebuah institusi perpustakaan (Astuti, 2016). Citra perpustakaan perlu dibangun agar dapat berkembang dengan baik untuk menjaga kepercayaan dan loyalitas pemustaka pada perpustakaan dalam memenuhi kebutuhannya. Dengan membangun citra yang positif, maka keberadaan perpustakaan akan membawa dan mengembangkan citra institusinya (Junaeti Junaeti, 2016). Citra institusi perguruan tinggi akan semakin baik apabila citra yang dari perputakaan tersebut dirasa positif. Dengan demikian, untuk dapat mengembangkan citra yang baik maka perpustakaan perlu berusaha meningkatkan layanan yang sesuai dengan standar yang telah ditetapkan, khususnya perpustakaan perguruan tinggi.
Peloza pada tahun 2011 menyatakan bahwa citra perusahaan akan meningkat apabila perusahaan mampu menyampaikan nilai yang superior kepada pelanggan (Limakrisna \& Mardo, 2016). Demikian perpustakaan, citra perpustakaan akan meningkat apabila mampu menyampaikan nilai yang positif kepada pemustaka. Nilai yang dimaksud dalam hal ini adalah nilai dari pelayanan baik atau bisa disebut sebagai pelayanan prima yang diberikan perpustakaan terhadap kebutuhan pemustaka khususnya informasi. Citra tidak secara instan terbentuk tanpa adanya stimulusstimulus atau pengaruh dari beberapa dimensi yang membentuk seseorang menganggap citra itu baik atau tidak. Pembentukan citra yang terdapat dalam benak konsumen terhadap suatu perusahaan yaitu dapat dilihat dari tiga indikator yang meliputi kesan, kepercayaan dan sikap (Sutojo, 2004).

Kesan yang diperoleh oleh konsumen terhadap suatu perusahaan dapat dijadikan sebagai indikatordalammenilai citraperusahaan. Terdapat beberapa contoh kesan yang didapat oleh konsumen seperti kesan terhadap pelayanan, program, hingga kesan konsumen saat melihat atau mendengar citra perusahaan terebut (Sutojo, 2004). Dengan demikian maka layanan, program atau kegiatan yang terdapat di perpustakaan tersebut akan menimbulkan kesan yang diperoleh akan menjadi persepsi tersendiri 
bagi konsumen terhadap suatu perusahaan. Persepsi diartikan sebagai hasil pengamatan terhadap unsur lingkungan yang dikaitkan dengan suatu proses pemaknaan (Soemirat \& Ardianto, 2010). Dengan hal ini dapat dinyatakan individu akan memberikan makna terhadap rangsang berdasarkan pengalamannya mengenai rangsang.

Kepercayaan atau keyakinan diri dari individu akan timbul melalui perkembangan kognisinya. terhadap stimulus disebut dengan kognisi. Keyakinan akan timbul apabila individu telah mengerti rangsang tersebut, sehingga individu harus diberikan informasi-informasi yang cukup yang dapat mempengaruhi perkembangan kognisinya (Soemirat \& Ardianto, 2010). Citra biasanya berakar dari nilai-nilai kepercayaan. Landasan citra itu berakar dari nilai-nilai kepercayaan yang kongkretnya diberikan secara individual, dan merupakan pandangan atau persepsi (Ruslan, 2014). Kepercayaan akan timbul dari konsumen karena rasa percaya yang ada kepada perusahaan yang memang memiliki kualitas sehingga seakan-akan mengikat dirinya seperti kejujuran, adil, bertanggung jawab, suka membantu dan rendah hati (Sutojo, 2004). Dari pernyataan tersebut, kualitas perpustakaan tentunya akan dapat meningkatkan kepercayaan pemustaka. Kepercayaan konsumen merupakan pengetahuan konsumen tentang suatu objek, atribut serta manfaat di mana objek tersebut baik berupa produk, orang, perusahaan, atau pun yang menjadi dasar keyakinan dan sikap seseorang (Sutrisno et al., 2016). Kepercayaan pemustaka sangat bermanfaat bagi perpustakaan agar pemustaka memiliki keyakinan dan kepercayaan yang kuat bahwa kebutuhan baik berupa koleksi maupun informasi lainya dapat merasa terpenuhi.

Sikap seseorang akan menentukan apakah seseorang tersebut harus bersikap peduli atau tidsk terhadap suatu hal yang diharapkan atau diinginkan. Sikap adalah kecenderungan bertindak, berpersepsi, berpikir, dan merasa dalam menghadapi objek, ide, situasi atau nilai (Soemirat \& Ardianto, 2010). Sikap pelanggan akan menjadi indikator dalam pengukuran citra suatu perusahaan, apabila pelanggan bersikap baik, maka citra perusahaan tersebut baik. Sebaliknya, jika pelanggan bersikap negatif, maka citra perusahaan tersebut dirasa kurang di mata pelanggan (Sutojo, 2004). Dari pernyataan tersebut, maka citra perpustakaan dapat dilihat baik atau tidak melalui sikap yang ditunjukkan oleh pemustakanya.

Membangun citra perpustakaan dapat dilakukan dengan berbagai cara, salah-satunya melalui penjalinan hubungan yang baik antara perpustakaan dengan pemustakanya melalui CRM. CRM memiliki tujuan utama untuk menciptakan kepuasan dan loyalitas 
pelanggan melalui bentuk-bentuk kegiatan dalam menciptakan relasi dengan pelanggan yang terorganisir dengan baik. Loyalitas pemustaka tentunya akan berpengaruh terhadap persepsi atau pandangan pemustaka yang dapat menilai baik atau tidaknya citra perpustakaan. Pengoptimalan nilai bagi pelanggan dapat berupa nilai-nilai kepercayaan. Begitupun di perpustakaan, nilai kepercayaan dari pemustaka yang dioptimalkan melalui CRM dapat mempengaruhi citra perpustakaan. Proses akumulasi dari amanah kepercayaan yang telah diberikan oleh individu-individu tersebut akan mengalami suatu proses cepat atau lambat akan membentuk suatu opini publik yang lebih luas, yaitu sering dinamakan citra (Ruslan, 2014). Pengaruh CRM terhadap peningkatan citra suatu lembaga atau perusahaan telah dibuktikan oleh beberapa penelitian tentang penerapan CRM tersebut. Pemustaka merupakan modal nyata bagi perpustakaan. Tanpa adanya pemustaka, perpustakaan akan kehilangan legitimasi serta nilainya (Fouad \& Al-Goblan, 2017). Di sini CRM bertujuan untuk membangun, mengorganisir, dan memelihara hubungan yang erat dengan pemustaka untuk periode terpanjang serta mengetahui kebutuhan pemustaka saat ini dan yang akan datang, hingga dapat menjamin kesetiaan pemustama kepada perpustakaan. Hsin, Huery \& Cheng papda tahun 2008 menyebutkan apabila pelanggan puas terhadap barang atau pelayanan yang diterima, maka akan menimbulkan kesetiaan konsumen (Anisa, 2016). Dengan kesetiaan yang ada melalui kepuasan pemustaka terhadap koleksi maupun layanan yang tersedia di perpustakaan, maka pemustaka dapat terus berminat untuk berkunjung kembali ke perpustakaan. Karena hal ini juga sesuai dengan hasil penelitian Hizrani menjelaskan bahwa kepuasan terhadap mutu pelayanan yang diberikan oleh rumah sakit akan mempengaruhi minat berkunjung kembali (Lutfiah \& Ayubi, 2008).

\section{METODE PENELITIAN}

Metode yang digunakan pada penelitian ini yaitu studi deskriptif dengan pendekatan kuantitatif. Teknik purposive sampling digunakan untuk menentukan sampel dan dengan bantuan rumus Solvin maka diperoleh sampel sebanyak 100 responden yang terdapat di dalam dan sekitar UPT Perpustakaan ITB dari jumlah keseluruhan populasi yaitu 34,500 mahasiswa ITB. (Diperoleh melalui ratarata kunjungan pemustaka pada bulan januari sampai dengan april 2018).

Kualitas hubungan antara pemustaka dengan perpustakaan menjadi alasan terbentuknya citra baik perpustakaan di mata pemustaka, sehingga perlu adanya beberapa indikator untuk mengukur seberapa besar pengaruh hubungan pemustaka terhadap citra 
melalui customer relationship management.

Teknik analisis data yang digunakan pada penelitian ini yaitu teknik analisis deskriptif melalui uji hipotesis dengan menggunakan analisis regresi linier sederhana. Dengan menggunakan teknik analisis deskriptif akan diketahui berbagai kecenderungan data, seperti rata-rata, median, standar deviasi dan varians untuk masing-masing variabel yang diteliti (Suryana, Zein, Sumartias, \& Gemiharto, 2019). Adapun teknik pengambilan data yang digunakan adalah melalui angket yang berupa kuesioner dalam bentuk pernyataan dengan skala jawaban berupa skala likert.

\section{HASIL DAN PEMBAHASAN}

Penelitian ini bertujuan untuk mengetahui bagaimana pengaruh customer relationship management (CRM) terhadap citra UPT Perpustakaan Institut Teknologi Bandung.

Berdasarkan tabel 1, dapat diketahui bahwa hasil uji t menghasilkan nilai $t_{\text {hitung }}$ sebesar 8,837 dan nilai signifikansi sebesar 0,000. Dengan nilai $\mathrm{t}_{\text {tabel }}=1,984$ (dilihat dari distribusi tabel $\mathrm{t}$ ) maka keputusannya yaitu jika nilai $\mathrm{t}_{\text {hitung }}>\mathrm{t}_{\text {tabel }}$

Tabel 1 Coefficients

\begin{tabular}{|c|c|c|c|c|c|c|}
\hline & & $\begin{array}{l}\text { Unstan } \\
\text { Coeffic }\end{array}$ & $\begin{array}{l}\text { dardized } \\
\text { ients }\end{array}$ & $\begin{array}{l}\text { Standardized } \\
\text { Coefficients }\end{array}$ & & \\
\hline & Model & B & $\begin{array}{l}\mathrm{S} \mathrm{t} \mathrm{d} . \\
\text { Error }\end{array}$ & Beta & $\mathrm{t}$ & Sig. \\
\hline 1 & $\begin{array}{l}\text { (Constant) } \\
\text { CRM }\end{array}$ & $\begin{array}{l}5,188 \\
, 567\end{array}$ & $\begin{array}{l}5,349 \\
, 064\end{array}$ & 666 & $\begin{array}{l}, 970 \\
8,837\end{array}$ & $\begin{array}{l}, 334 \\
, 000\end{array}$ \\
\hline
\end{tabular}

maka $\mathrm{H}_{1}$ diterima, sedangkan jika nilai $\mathrm{t}_{\text {hitung }}<$ $\mathrm{t}_{\text {tabel }}$ maka $\mathrm{H}_{1}$ ditolak. Sehingga dapat ditarik kesimpulan bahwa $\mathrm{t}_{\text {hitung }} 8,837>\mathrm{t}_{\text {tabel }} 1,984$ maka $\mathbf{H}_{1}$ diterima dan $\mathbf{H}_{\mathbf{0}}$ ditolak. Sehingga dapat diartikan bahwa terdapat pengaruh yang signifikan antara customer relationship management (variabel $\mathrm{X}$ ) terhadap citra perpustakaan (variabel Y).

Berdasarkan tabel 2, dapat diketahui bahwa hasil uji koefisien determinasi menghasilkan nilai korelasi $(\mathrm{R})$ sebesar 0,666 dan diperoleh nilai koefisien determinasi (R Square) sebesar 0,443. Dari hasil tersebut maka dapat ditarik kesimpulan bahwa pengaruh customer relationship management (variabel $\mathrm{X}$ ) terhadap citra perpustakaan (variabel Y) yaitu sebesar $\mathbf{4 4 , 3 \%}$ dan $55,7 \%$ lainnya dipengaruhi oleh faktor-faktor di luar variabel X.

Data yang diperoleh dari 100 responden melalui kuesioner penelitian menunjukan bahwa pengaruh customer relationship management yang diterapkan di UPT Perpustakaan ITB cukup kuat sehingga dapat dikatakan bahwa penerapan customer relationship management di UPT Perpustakaan ITB sudah cukup baik.

Tabel 2 Model Summary

\begin{tabular}{ccclc}
\hline Model & $\mathrm{R}$ & $\begin{array}{c}\mathrm{R} \\
\text { Square }\end{array}$ & $\begin{array}{l}\text { Adjusted } \\
\mathrm{R} \\
\text { Square }\end{array}$ & $\begin{array}{c}\text { Std. } \\
\text { Error of } \\
\text { the } \\
\text { Estimate }\end{array}$ \\
\hline 1 &, $666 \mathrm{a}$ &, 443 &, 438 & 8,24690 \\
\hline
\end{tabular}


Sementara itu, berdasarkan hasil kuesioner yang telah diperoleh menunjukan bahwa citra yang dimiliki oleh UPT Perpustakaan ITB termasuk dalam kategori kuat sehingga dapat dikatakan bahwa UPT Perpustakaan ITB memiliki citra yang baik menurut pandangan pemustaka. Hal ini sesuai dengan yang dikemukakan oleh Buttle F. bahwa customer relationship management apabila di dalam konteks non profit, maka akan mampu dalam meningkatkan kepuasan pada pelanggannya (Buttle, 2004). UPT Perpustakaan ITB menerapkan strategi customer relationship management sudah cukup baik kepada pemustaka.

Berdasarkan hasil pengolahan data, menunjukkan bahwa customer relationship management meiliki pengaruh yang positif dan signifikan terhadap citra perpustakaan. Hal tersebut dibuktikan dengan arah regresi yang positif, menunjukkan pengaruh yang cukup kuat.

Hubungan antara perusahaan dengan pelanggan akan meningkat dengan harapan akan tetap memiliki kesetiaan pada perusahaan (Nuraryo, 2019). Seperti penelitian yang dilakukan oleh Fouad dan Al-Goblan yang berjudul "Using customer relationship management systems at university libraries: A comparative study between Saudi Arabia and Egypt", penelitian ini bertujuan untuk untuk mensurvei potensi implementasi hubungan pelanggan sistem manajemen di perpustakaan universitas . Dari hasil penelitian ini menunjukan bahwa 99,0\% dari peserta studi dari perpustakaan universitas Mesir dan Saudi yakin akan pentingnya sistem CRM (Fouad \& Al-Goblan, 2017).

Untuk mengetahui seberapa besar pengaruh data dan teknologi customer relationship management (CRM) terhadap citra UPT Perpustakaan Institut Teknologi Bandung.

Berdasarkan tabel 3, dapat diketahui bahwa hasil uji t menghasilkan nilai $\mathrm{t}_{\text {hitung }}$ sebesar 8,967 dan nilai signifikansi sebesar 0,000. Dengan nilai $\mathrm{t}_{\text {tabel }}=1,984$ (dilihat dari distribusi tabel $\mathrm{t}$ ) maka keputusannya yaitu jika nilai $t_{\text {hitung }}>t_{\text {tabel }}$ maka $\mathrm{H}_{1}$ diterima, sedangkan jika nilai $\mathrm{t}_{\text {hitung }}<$ $\mathrm{t}_{\text {tabel }}$ maka $\mathrm{H}_{1}$ ditolak. Sehingga dapat ditarik kesimpulan bahwa $\mathrm{t}_{\text {hitung }} 8,967>\mathrm{t}_{\text {tabel }} 1,984$ maka $\mathbf{H}_{1}$ diterima dan $\mathbf{H}_{\mathbf{0}}$ ditolak. Sehingga dapat diartikan bahwa terdapat pengaruh yang signifikan antara data dan teknologi (sub variabel $\mathrm{X}_{1}$ ) terhadap citra perpustakaan (variabel Y).

\section{Tabel 3 Coefficientsa}

\begin{tabular}{|c|c|c|c|c|c|c|}
\hline & & $\begin{array}{l}\text { Unstan } \\
\text { Coeffi }\end{array}$ & $\begin{array}{l}\text { ardized } \\
\text { ents }\end{array}$ & $\begin{array}{l}\text { Standard } \\
\text { ized } \\
\text { Coeffic } \\
\text { ients }\end{array}$ & & \\
\hline & Model & B & $\begin{array}{l}\mathrm{Std} . \\
\text { Error }\end{array}$ & Beta & $\mathrm{t}$ & sig \\
\hline 3 & $\begin{array}{l}\text { (Constant) } \\
\text { Proses } \\
\text { CRM }\end{array}$ & $\begin{array}{l}8,874 \\
3,278\end{array}$ & $\begin{array}{l}2,874 \\
, 108\end{array}$ & ,951 & $\begin{array}{l}3,088 \\
30,487\end{array}$ & $\begin{array}{l}, 003 \\
, 000\end{array}$ \\
\hline
\end{tabular}


Data yang diperoleh dari 100 responden melalui kuesioner penelitian menunjukan bahwa data dan teknologi customer relationship management yang dikelola oleh UPT Perpustakaan ITB cukup kuat sehingga dapat dikatakan bahwa pengelolaan data dan teknologi customer relationship management di UPT Perpustakaan ITB sudah cukup baik. Hal ini sesuai dengan pernyataan Petugas harus memperoleh data tentang pelanggan untuk memperoleh hubungan yang erat (Buttle, 2004).

Berdasarkan hasil pengolahan data, aspek data dan teknologi customer relationship management meiliki pengaruh yang positif dan signifikan terhadap citra perpustakaan. Hal tersebut dibuktikan dengan arah regresi yang positif, menunjukkan pengaruh yang cukup kuat.

Untuk mengetahui seberapa besar pengaruh sumber daya manusia customer relationship management (CRM) terhadap citra UPT Perpustakaan Institut Teknologi Bandung.

Berdasarkan tabel 4, dapat diketahui bahwa

\section{Tabel 4 Coefficientsa}

\begin{tabular}{|c|c|c|c|c|c|c|}
\hline & & $\begin{array}{l}\text { Unstand } \\
\text { Coeffici }\end{array}$ & $\begin{array}{l}\text { ardized } \\
\text { nts }\end{array}$ & $\begin{array}{l}\text { Standard } \\
\text { ized } \\
\text { Coeffic } \\
\text { ients }\end{array}$ & & \\
\hline & Model & B & $\begin{array}{l}\mathrm{Std} \text {. } \\
\text { Error }\end{array}$ & Beta & $\mathrm{t}$ & sig \\
\hline 2 & $\begin{array}{l}\text { (Constant) } \\
\text { Sumber } \\
\text { Daya } \\
\text { Manusia }\end{array}$ & $\begin{array}{l}11,017 \\
2,554\end{array}$ & $\begin{array}{l}3,635 \\
, 109\end{array}$ & ,922 & $\begin{array}{l}3,031 \\
23,500\end{array}$ & $\begin{array}{l}, 003 \\
, 000\end{array}$ \\
\hline
\end{tabular}

hasil uji tmenghasilkan nilai $t_{\text {hitung }}$ sebesar 23,500 dan nilai signifikansi sebesar 0,000. Dengan nilai $\mathrm{t}_{\text {tabel }}=1,984$ (dilihat dari distribusi tabel $\mathrm{t}$ ) maka keputusannya yaitu jika nilai $\mathrm{t}_{\text {hitung }}>\mathrm{t}_{\text {tabel }}$ maka $\mathrm{H}_{1}$ diterima, sedangkan jika nilai $\mathrm{t}_{\text {hitung }}<$ $\mathrm{t}_{\text {tabel }}$ maka $\mathrm{H}_{1}$ ditolak. Sehingga dapat ditarik kesimpulan bahwa $\mathrm{t}_{\text {hitung }} 23,500>\mathrm{t}_{\text {tabel }} 1,984$ maka $\mathrm{H}_{1}$ diterima dan $\mathrm{H}_{0}$ ditolak. Sehingga dapat diartikan bahwa terdapat pengaruh yang signifikan antara sumber daya manusia $\left(\right.$ sub variabel $\mathrm{X}_{2}$ ) terhadap citra perpustakaan (variabel Y).

Data yang diperoleh dari 100 responden melalui kuesioner penelitian menunjukan bahwa sumber daya manusia customer relationship management yang ditugaskan oleh UPT Perpustakaan ITB termasuk dalam kategorikuat sehingga dapat dikatakan bahwa sumber daya manusia yang melaksanakan kegiatan customer relationship management di UPT Perpustakaan ITB sudah baik. Hal ini sesuai dengan pernyataan Buttle (2004:71) bahwa "salah satu organisasi relokasi global terkemuka menemukan bahwa penerapan strategi CRM membutuhkan banyak partisipasi, pemahaman, dan penguatan di antara pegawai”. Pustakawan UPT Perpustakaan ITB dapat melaksanakan strategi customer relationship management dengan baik sesuai dengan hasil yang telah diperoleh dalam penelitian ini.

Berdasarkan hasil pengolahan data 
Tabel 5 Coefficientsa

\begin{tabular}{lllllll}
\hline \multicolumn{1}{c}{} & & $\begin{array}{l}\text { Unstandardized } \\
\text { Coefficients }\end{array}$ & $\begin{array}{l}\text { Standardized } \\
\text { Coefficients }\end{array}$ & & \\
\hline & Model & B & $\begin{array}{l}\text { S t d . } \\
\text { Error }\end{array}$ & Beta & t & sig \\
\hline 1 & (Constant) & 43,877 & 5,844 & & 7,508 &, 000 \\
& Data dan \\
& Teknologi & 2,230 &, 249 &, 671 & 8,967 &, 000 \\
\hline
\end{tabular}

customer relationship management meiliki pengaruh yang positif dan signifikan terhadap citra perpustakaan. Hal tersebut dibuktikan dengan arah regresi yang positif, menunjukkan pengaruh yang kuat.

Untuk mengetahui seberapa besar pengaruh proses customer relationship management $(C R M)$ terhadap citra UPT Perpustakaan Institut Teknologi Bandung.

Berdasarkan tabel 5, dapat diketahui bahwa hasil uji t menghasilkan nilait ${ }_{\text {hitung }}$ sebesar 30,487 dan nilai signifikansi sebesar 0,000. Dengan nilai $\mathrm{t}_{\text {tabel }}=1,984$ (dilihat dari distribusi tabel $\mathrm{t}$ ) maka keputusannya yaitu jika nilai $\mathrm{t}_{\text {hitung }}>\mathrm{t}_{\text {tabel }}$ maka $\mathrm{H}_{1}$ diterima, sedangkan jika nilai $\mathrm{t}_{\text {hitung }}<$ $\mathrm{t}_{\text {tabel }}$ maka $\mathrm{H}_{1}$ ditolak. Sehingga dapat ditarik kesimpulan bahwa $t_{\text {hitung }} 30,487>t_{\text {tabel }} 1,984$ maka $\mathrm{H}_{1}$ diterima dan $\mathrm{H}_{0}$ ditolak. Sehingga dapat diartikan bahwa terdapat pengaruh yang signifikan antara proses CRM (sub variabel $\mathrm{X}_{3}$ ) terhadap citra perpustakaan (variabel Y).

Data yang diperoleh dari 100 responden melalui kuesioner penelitian menunjukan bahwa proses customer relationship management yang diterapkan di UPT Perpustakaan ITB termasuk ke dalam kategorikuat sehingga dapat dikatakan bahwa proses customer relationship management yang dilakukan di UPT Perpustakaan ITB sudah baik. Hal ini sesuai dengan pernyataan Buttle bahwa jika dilihat dari perspektif customer relationship management, proses perlu dirancang dan dioperasikan sehingga mereka berkontribusi bagi penciptaan nilai atau setidaknya tidak merusak nilai yang telah diciptakan bagi pelanggan (Buttle, 2004). Proses yang mendukung terlaksananya customer relationship management dapat memberikan nilai kepercayaan, kesan, maupun sikap pemustaka terhadap kinerja perpustakaan. UPT Perpustakaan ITB sudah melaksanakan proses customer relationship management dengan baik dalam memperoleh citra yang positif bagi perpustakaan.

Berdasarkan hasil pengolahan data customer relationship management meiliki pengaruh yang positif dan signifikan terhadap citra perpustakaan. Hal tersebut dibuktikan dengan arah regresi yang positif, menunjukkan pengaruh yang kuat.

\section{SIMPULAN}

Kesimpulan umum pada penelitian ini menunjukkan bahwa Customer Relationship Management (CRM) berpengaruh positif dan signifikan terhadap Citra Perpustakaan UPT Perpustakaan Institut Teknologi Bandung. 
Customer Relationship Management (CRM) terhadap citra perpustakaan yaitu adanya pengaruh yang signifikan dan kontribusi yang cukup kuat dari aspek data dan teknologi CRM terhadap citra UPT Perpustakaan ITB, adanya pengaruh yang signifikan dan kontribusi yang kuat dari aspek sumber daya manusia CRM terhadap citra UPT Perpustakaan ITB, serta adanya pengaruh yang signifikan dan kontribusi yang kuat dari aspek proses CRM terhadap citra UPT Perpustakaan ITB.

UPT Perpustakaan ITB sebaiknya dapat memanfaatkan dengan maksimal data tentang informasi pemustaka dalam menjalin hubungan yang baik antara perpustakaan dengan pemustaka melalui jaringan komunikasi baik dalam bentuk nomor telepon, email, atau jaringan komuikasi lainnya seperti info koleksi perpustakaan terbaru maupun kegiatan layanan perpustakaan lainnya. Kemudian dalam hal layanan online perpustakaan sebaiknya lebih mensosialisasikan penggunaan layanan online seperti forum diskusi yang telah tersedia pada website UPT Perpustakaan ITB agar lebih dimanfaatkan dengan maksimal oleh pemustaka. Serta secara berkesinambungan memfasilitasi pemustaka dalam menyampaikan keluhan maupun saran untuk pengembangan layanan perpustakaan. Hal ini dikarenakan masih banyak pemustaka yang merasa malu atau tidak tahu harus kemana menyampaikan saran atau aspirasi pemustaka pada perpustakaan.

Adapun bagi peneliti selanjutnya yaitu diharapkan untuk lebih mengembangkan dan melengkapi keilmuan yang berkaitan dengan customer relationship management di bidang perpustakaan daninformasi sehingga tidak hanya menghubungkan dengan citra perpustakaan. Dengan demikian maka keterkaitan antara customer relationship management dengan ilmu perpustakaan akan lebih luas.

\section{DAFTAR PUSTAKA}

Anisa, R. (2016). Manajemen kerelasian pelanggan dalam menciptakan kepercayaan pelanggan pada commercial banking center Bandung pt. bank mandiri (Persero) Tbk. Jurnal Kajian Komunikasi, 4(1), 43-50.

Astuti, P. (2016). Membangun citra perpustakaan perguruan tinggi. JIPI: Jurnal Ilmu Perpustakaan Dan Informasi, 1(1), 206-225.

Brambilla, F. R., \& Dalmarco, G. (2014). Management of customer relationship management (crm) technological attributes in brazil: a b2b relationship in the softwaremedia development sector. Faces: Revista de Administracao, 13(4), 39-56.

Buttle, F. (2004). Customer relationship management: concepts and tools (manajemen hubungan pelanggan). Malang: Buku Media Publishing.

Darudiato, S., Novianto, C., Hendra, H., Reynaldo, R., \& Selvi, S. (2011). Membangun customer relationship management dalam bisnis. ComTech, 2(2), 1350-1358. Retrieved from https:// www.neliti.com/publications/165908/ 
membangun-customer-relationshipmanagement-dalam-bisnis

Fouad, N., \& Al-Goblan, N. (2017). Using customer relationship management systems at university libraries: A comparative study between Saudi Arabia and Egypt. International Federation of Library Associations and Institutions, 43(2), 158170.

Gunawan, A. W. (2008). Literasi informasi: 7 langkah knowledge management. Jakarta: Universitas Atmajaya.

Habir. (2015). Pengaruh layanan perpustakaan terhadap minat kunjung pemustaka di perpustakaan STIKES Mega Rezky Makassar. Jurnal Ilmu Perpustakaan, Informasi, Dan Kearsipan Khizanah AlHikmah, 3(2), 156-171.

Irina, B., \& Diana, Ş. I. M. (2009). Building a relationship with the customer: a crm versus a qm perspective. Annals of The University Of Oradea, 4(1), 586-590.

Junaeti Junaeti, A. A. (2016). Peranan perpustakaan dalam meningkatkan kualitas perguruan tinggi (konstruksi pelayanan, strategi, dan citra perpustakaan). Libraria: Jurnal Perpustakaan, 4(1), 27-54.

Klimanov, D., \& Frolkina, E. (2015). The impact of crm system use on companies' customer understanding: the case of the russian ophthalmology market. Trziste, 27(1), 75-92.

Limakrisna, N., \& Mardo, S. A. (2016). Determinan dari nilai pelayanan dan citra institusi sistem nsw di Indonesia. MIX: Jurnal Ilmiah Manajemen, 6(1), 14-27.

Lutfiah, L., \& Ayubi, D. (2008). Dimensi kepuasan yang berhubungan dengan niat berkunjung kembali di layanan rawat jalan rumah sakit umum daerah (rsud) Serang tahun 2007. JKMA: Jurnal Kesehatan
Masyarakat Andalas, 3(1), 5-9.

Mohammad, R., \& Tahir, S. (2013). Assessing the influence of customer relationship management (CRM) dimensions on organization performance: An emperical study in the hotel industry. Journal of Hospitality and Tourism Technology, 4(3), 228-247.

Mubasyaroh. (2016). Pengaruh perpustakaan bagi peningkatan mutu pendidikan perguruan tinggi. Libraria: Jurnal Perpustakaan, 4(1), 77-104.

Negoro, S. H. (2014). Kredibilitas customer service dan citra perusahaan. Jurnal Ilmu Komunikasi, 11(2), 215-230.

Ningsih, N. W., \& Suharyono, E. Y. (2016). Pengaruh customer relationship management (CRM) terhadap kepuasan dan loyalitas pelanggan. Jurnal Administrasi Bisnis, 30(1), 172-177.

Nuraryo, I. (2019). Model pengembangan kualitas hubungan students college exchange berbasis public relations evaluation. PRofesi Humas, 3(2), 255-272.

Oesman, Y. M. (2010). Sukses mengelola marketing mix, crm, customer value, dan customer dependency. Bandung: Alfabeta.

Prastowo, A. (2012). Manajemen perpustakaan sekolah profesional. Yogyakarta: Diva Press.

Putri, N. E., Hakim, N., \& Yamin, M. (2016). Ecologicall footprint and biocapacity analysis for flooding prevention in South Sumatera. Jurnal Mimbar, 32(1), 58-64.

Ruslan, R. (2014). Manajemen publik relations dan media komunikasi: konsepsi dan aplikasi. Jakarta: Rajawali Pers.

Saleh, A. R., \& Komalasari, R. (2009). Manajemen perpustakaan. Jakarta: Universitas Terbuka.

Soemirat, S., \& Ardianto, E. (2010). Dasar- 
dasar public relations. Bandung: Remaja Rosdakarya.

Suryana, A., Zein, D., Sumartias, S., \& Gemiharto, I. (2019). Pengaruh straegi komunikasi organisasi, budaya organisasi, karakteristik individu inovatif dan komitmen organisasional terhadap kinerja usaha kecil dan menengah. Jurnal Manajemen Komunikasi, 3(2), 185-201. Retrieved from http://jurnal.unpad. ac.id/manajemen-komunikasi/article/ view/20754/pdf

Sutojo, S. (2004). Membangun citraperusahaan. Jakarta: Damar Mulia Pustaka.

Sutrisno, Brahmasari, I. A., \& Panjaitan, H.
(2016). The influence of service quality, and customer relationship management (CRM) of patient satisfaction, brand image, trust, and patient loyalty on Indonesian national army level ii hospitals. International Journal of Business and Management Invention, 5(5), 30-44.

Wijaya, A. E. H., \& Sukawati, T. G. R. (2016). Pengaruh customer relationship management (CRM) dan good corporate governance (GCG) terhadap citra (image) perusahaan (studi pada perusahaan daerah air minum tirta mangutama kabupaten Bandung). E-Jurnal Manajemen Unud, 5(7), $4071-4100$. 